\title{
Low Input Weed Management in Field Peas
}

\author{
Z. Munakamwe", B.A. McKenzie and G.D. Hill
}

Agriculture Group, Agriculture and Life Science Division, P.O. Box 84, Lincoln University, 7647, New Zealand.

\begin{abstract}
Two trials were conducted on a Templeton silt loam soil at Lincoln University, New Zealand $\left(43^{\circ} 38^{\prime} \mathrm{S}, 172^{\circ}\right.$ $28^{\prime}$ E.) in $2007 / 08$. The aim was to compare the competitive ability of different pea canopy architectures as influenced by genotype, population, sowing date and their interaction as a means of low input weed control strategy. The first experiment had three sowing dates, two pea genotypes and two herbicide treatments. Experiment 2 treatments were a factorial combination of four pea populations and three sown artificial weed populations. A significant sowing date $\mathrm{x}$ pea genotype interaction showed that in the August sowing genotype had no effect on seed yield. However, in September sown plots Pro 7035 yielded $559 \mathrm{~g} \mathrm{~m}^{-2}$, which was $40 \%$ more than Midichi, and in the October sowing, the difference was $87 \%$ more. Herbicide-sprayed peas produced $19 \%$ more seed $\left(508 \mathrm{~g} \mathrm{~m}^{-2}\right)$ than the unsprayed plants. When no weeds were sown, the highest pea total dry matter (TDM) of $1,129 \mathrm{~g} \mathrm{~m}^{-2}$ occurred at 200 plants $\mathrm{m}^{-2}$. This was more than twice $\left(513 \mathrm{~g} \mathrm{~m}^{-2}\right)$ the yield of the lowest population $\left(50\right.$ plants $\mathrm{m}^{-2}$ ). There was distinct variation in the weed spectrum over time. Coronopus didymus, Stellaria media and Lolium spp were present in relatively large numbers throughout the season. Some weeds only occurred late in the season meaning they could be successfully controlled by early sowing. It could be concluded that it is possible to obtain high pea yields by using the right sowing date and appropriate seed rate as a means of low input weed management strategy.
\end{abstract}

Keywords: Genotype, low input, population, sowing date, cyanazine, weed spectrum, semi-leafless.

\section{INTRODUCTION}

The poor ability of pea crops to compete with weeds [1, $2]$ is the major drawback of growing them under low input or organic systems. Weeds can cause severe yield losses if crops are not monitored closely, particularly during the early stages of weed emergence [3]. Generally, poor weed management results in weed accumulation and a larger weed seed bank. Farmers usually use conventional herbicides to manage weeds but low input farmers try to use less of that and the use of synthetic herbicides is not allowed in organic production systems. They currently mostly rely on cultural control methods. Weed control is therefore a real constraint in these systems.

Some methods to control weeds under low input systems include intercropping and crop rotation [4], use of competitive crop genotypes $[5,7]$, mechanical and hand weeding, use of appropriate sowing date and, often, high sowing rates [8]. Several crops show genotypic differences in their competitive ability $[8,9]$ mostly related to plant architecture, leaf area, leaf angle, plant stature, seed and seedling vigour. Also different weed species have different competitive abilities with crops [10].

Viability of low input and organic systems depends on achieving acceptable yields. Freeman [3] stressed that consistent yields of around $4 \mathrm{tha}^{-1}$ are necessary for field

*Address correspondence to this author at the Department of Primary Industries, Victoria, Australia; Tel: 0061409511032; Fax: 0061-3-54304304;

Emails: munakamwez@yahoo.com, zachariah.munakamwe@dpi.vic.gov.au peas to be a viable crop. According to Moot [11], White and Hill [12], these high pea yields are achievable under favourable conditions despite peas' poor yield stability [13, 14].

The research objective of this work was to compare the competitive ability of different pea canopy architectures as influenced by genotype (conventional and semi-leafless), population, sowing date and their interaction as a means of low input weed control strategy.

\section{MATERIALS AND METHODS}

Two trials were conducted in $2007 / 08$ on a Templeton silt loam soil [15] at the Horticulture Research Area, Lincoln University, Canterbury, New Zealand $\left(43^{\circ} 38^{\prime} \mathrm{S}, 172^{\circ} 28^{\prime}\right.$ E.). MAF soil quick tests [16] were done to establish actual soil available nutrient levels (Table 1). All the nutrient levels were in the acceptable range for growing peas and the $\mathrm{pH}$ was also optimal.

In experiment 1 , treatments were arranged in a split plot design with three replicates. Main plots were sown on 9 August, 13 September and 15 October 2007. Sub-plots were a factorial combination of two pea genotypes, conventional (Pro 7035) and semi-leafless (Midichi) and two herbicide treatments (cyanazine at 0 and $500 \mathrm{~g}$ a.i. $\mathrm{ha}^{-1}$ ) applied before emergence. The total number of plots was 54 (36 plots with peas and 18 no pea control plots). Each plot was $2.1 \mathrm{~m}$ wide x $10 \mathrm{~m}$ long. Experiment 2 was sown on 13 September and the treatments were a factorial combination of four pea populations $(0,0.5 \mathrm{x}$ recommended sowing rate, recommended sowing rate $\left(100\right.$ plants $\left.\mathrm{m}^{-2}\right), 2.0 \mathrm{x}$ recommended), and three 
Table 1. MAF Soil Quick Test for Paddocks H14 and H3, Horticulture Research Area, Lincoln University.

\begin{tabular}{|c|c|c|c|c|c|c|}
\hline Experiment & $\mathbf{p H}$ & $\begin{array}{c}\text { Olsen-Soluble } \\
\mathbf{P}\left(\boldsymbol{\mu g} \mathbf{~ m}^{-\mathbf{1}}\right)\end{array}$ & $\mathbf{C a}$ & $\mathbf{M g}$ & $\mathbf{K}$ & Sulphate $\left(\boldsymbol{\mu g} \mathbf{g}^{-\mathbf{1}}\right)$ \\
\hline \hline $\mathrm{1}$ and 2 & 6 & 15 & 7 & 21 & 10 & 6 \\
\hline $\mathrm{Ca}, \mathrm{Mg}, \mathrm{K}$, and $\mathrm{Na}$ as $\mathrm{mg} / \mathrm{g}$ of soil
\end{tabular}

sown artificial weed populations $(0,1 / 3$ recommended (referred to here as lower rate) and $2 / 3$ recommended (referred to here as higher rate) of each weed. The sown artificial weeds were a mixture of Brassica napus, Lolium multiflorum and Vicia sativa which had recommended sowing rates of 3 , 25 and $30 \mathrm{~kg} \mathrm{ha}^{-1}$ respectively when sown as crops and this translated to 100,833 and 75 seeds $\mathrm{m}^{-2}$ respectively. This was a good representation of a broad spectrum of weeds commonly found in most fields. The experiment design was a randomised complete block with three replicates. The total number of plots was 36. Each plot was $2.1 \mathrm{~m} \mathrm{x} 6 \mathrm{~m}$ long. The field pea variety used was Midichi (a semi-leafless type).

\section{HUSBANDRY}

Land was prepared using conventional methods, i.e. disking, rolling and harrowing. It was tilled to a depth of $25 \mathrm{~cm}$. Seed was drilled with an Öyjord cone seeder at a depth of 5 $\mathrm{cm}$. In experiment 1 , seed was sown in $15 \mathrm{~cm}$ rows and was sown at 100 plants $\mathrm{m}^{-2}$ at the above-stated sowing dates. Wakil, a formulated mixture of metalaxyl, fludioxonil and cymoxanil for the control of Peronospora spp (downy mildew), Pythium spp and Ascochyta spp, was applied to all seed at the equivalent of $2 \mathrm{~kg} \mathrm{t}^{-1}$ of seed before sowing. All sowing rates were corrected for germination percentage and expected field emergence for each pea variety. Experiment 2 was sown on 13 September in $15 \mathrm{~cm}$ rows with varying intra row spacing to achieve pea populations of 50, 100 and 200 plants $\mathrm{m}^{-2}$. The sown weed seed was then broadcasted onto plots and lightly harrowed to incorporate them into the soil.

Irrigation was applied based on crop requirement as determined by Time Domain Reflectometry (TDR) in the 0 $20 \mathrm{~cm}$ soil layer, when the soil reached $50 \%$ of field capacity based on the first sowing date. A mini boom irrigator applied $30 \mathrm{~mm}$ of water at each irrigation. A total of $120 \mathrm{~mm}$ was applied to both experiments. The peas were sprayed with cyproconazole at $250 \mathrm{ml} \mathrm{ha}{ }^{-1}$ to combat powdery mildew (Erysiphe spp) and with copper oxychloride at $1 \mathrm{~kg} \mathrm{ha}^{-1}$ for downy mildew in both experiments.

\section{MEASUREMENTS AND ANALYSIS}

A $0.2 \mathrm{~m}^{2}$ sample was taken from each plot using a $0.1 \mathrm{~m}^{2}$ quadrat every 7-10 days throughout the season starting from three weeks after crop emergence. This was used for crop and weed dry matter measurements. Samples were dried in a forced draught oven for $24-48 \mathrm{~h}$ at $60{ }^{\circ} \mathrm{C}$ to a constant weight and then weighed. Final harvests were taken when crops reached a moisture content of $15-18 \%$. Final total $\mathrm{DM}$ and seed yield were estimated from $1 \mathrm{~m}^{2}$ quadrat samples. Plants were cut at ground level and weighed. They were hand threshed and the seeds weighed. Weed counts were taken three times during the growing season and this was at
10 weeks after emergence of each sowing date. Weeds were sorted by taxa (species or genus depending on similarity) and counted. Uncommon taxa were pooled and their total count recorded.

All data were subjected to the analysis of variance (ANOVA). Genstat 10.1. Copyright 2007, Lawes Agricultural Trust (Rothamsted Experimental Station) was used for statistical analysis. Means were separated at the 5\% level of significance using least significance difference (LSD) for sowing date, herbicide, genotype, population and interactions effects.

\section{RESULTS}

\section{Climate}

Climate data were from the Broadfields Meteorological Station, Lincoln University located about $1.5 \mathrm{~km}$ from the experimental site. The 2007/08 growing season was generally dry, with January rainfall being just $38 \%$ of the longterm average (Fig. 1). Substantial rain fell at the end of the season in February (104 mm). The season was generally cool and all mean temperatures, except in September, were lower than long-term means (Fig. 2).

\section{Crop Yield and Harvest Index}

Total DM at final harvest of the August and September sowings were not significantly different (mean $1,018 \mathrm{~g} \mathrm{~m}^{-2}$ ) but they were significantly higher was from the October sowing and cyanazine sprayed plots produced $21 \%$ more TDM than unsprayed plots $\left(788 \mathrm{~g} \mathrm{~m}^{-2}\right)$ (Table 2). There was no significant difference in the mean TDM produced by the two pea cultivars Midichi and Pro 7035 (mean $941 \mathrm{~g} \mathrm{~m}^{-2}$ ).

Herbicide sprayed peas produced 19\% more seed (508 g $\mathrm{m}^{-2}$ ) than the unsprayed plants (Table 2). A significant $(\mathrm{p}<$ 0.05 ) sowing date $x$ pea genotype interaction showed that in the August, sowing genotype had no effect on seed yield (Table 3). However, in September sown plots Pro 7035 yielded $559 \mathrm{~g} \mathrm{~m}^{-2}$, which was $40 \%$ more than Midichi, and in the October sowing, the difference was $87 \%$ more.

Herbicide had no effect on crop harvest index (CHI). Pro 7035 had a higher CHI than Midichi (0.56). There was a significant sowing date $\mathrm{x}$ genotype interaction for $\mathrm{CHI}$ (Table 4). This showed that in August sowing there was less difference in CHI between the two cultivars than at the other two sowing dates.

In experiment 2 , dry matter accumulation was directly proportional to pea population throughout the season and growth curves for each population had a typical sigmoidal shape (Fig. 3). The highest pea TDM was achieved at 200 plants $\mathrm{m}^{-2}\left(1,120 \mathrm{~g} \mathrm{~m}^{-2}\right)$, which was more than twice the yield 


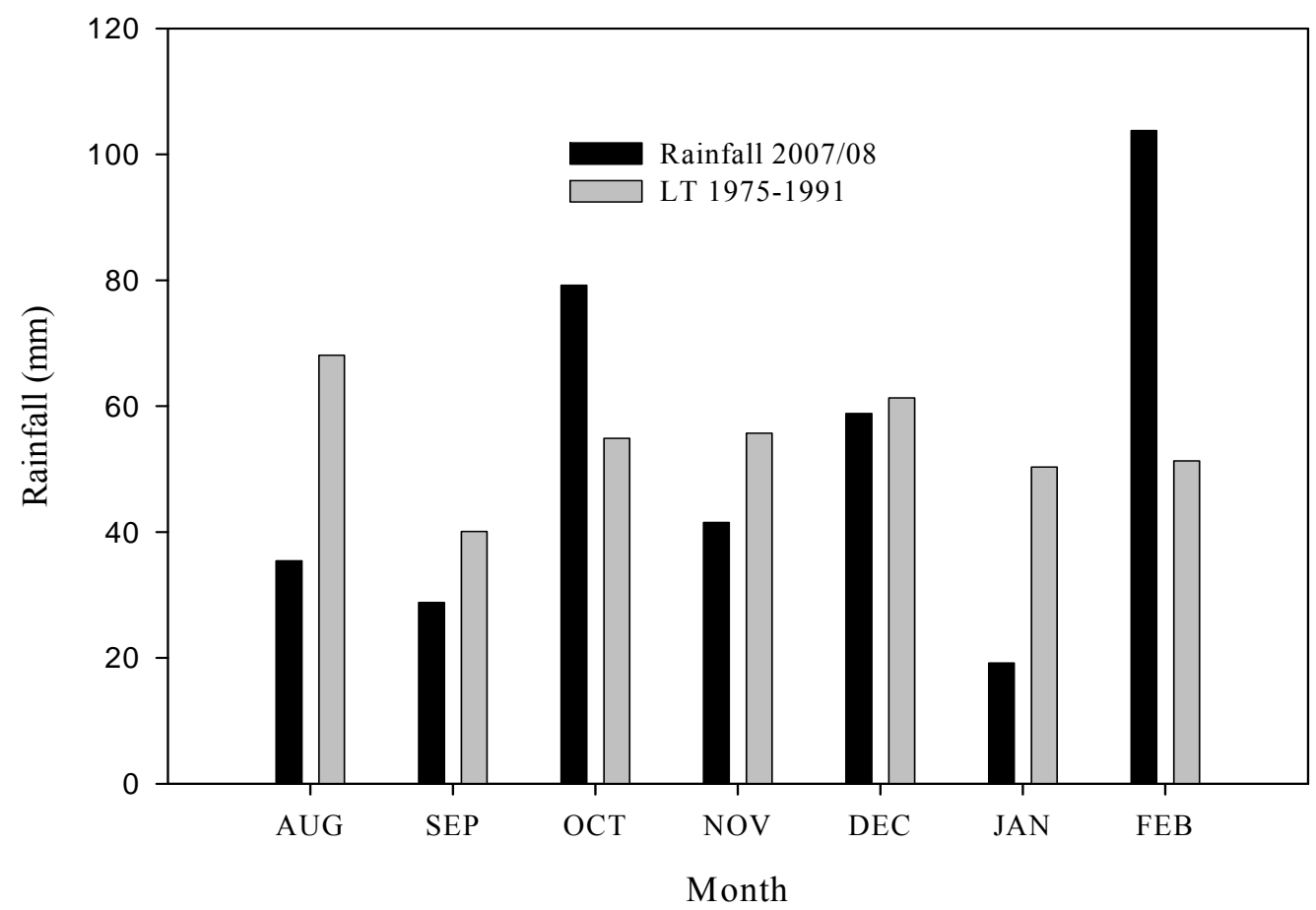

Fig. (1). Rainfall data for Broadfields, Canterbury, in the 2007/08 growing season and long term mean $1975-1991$.

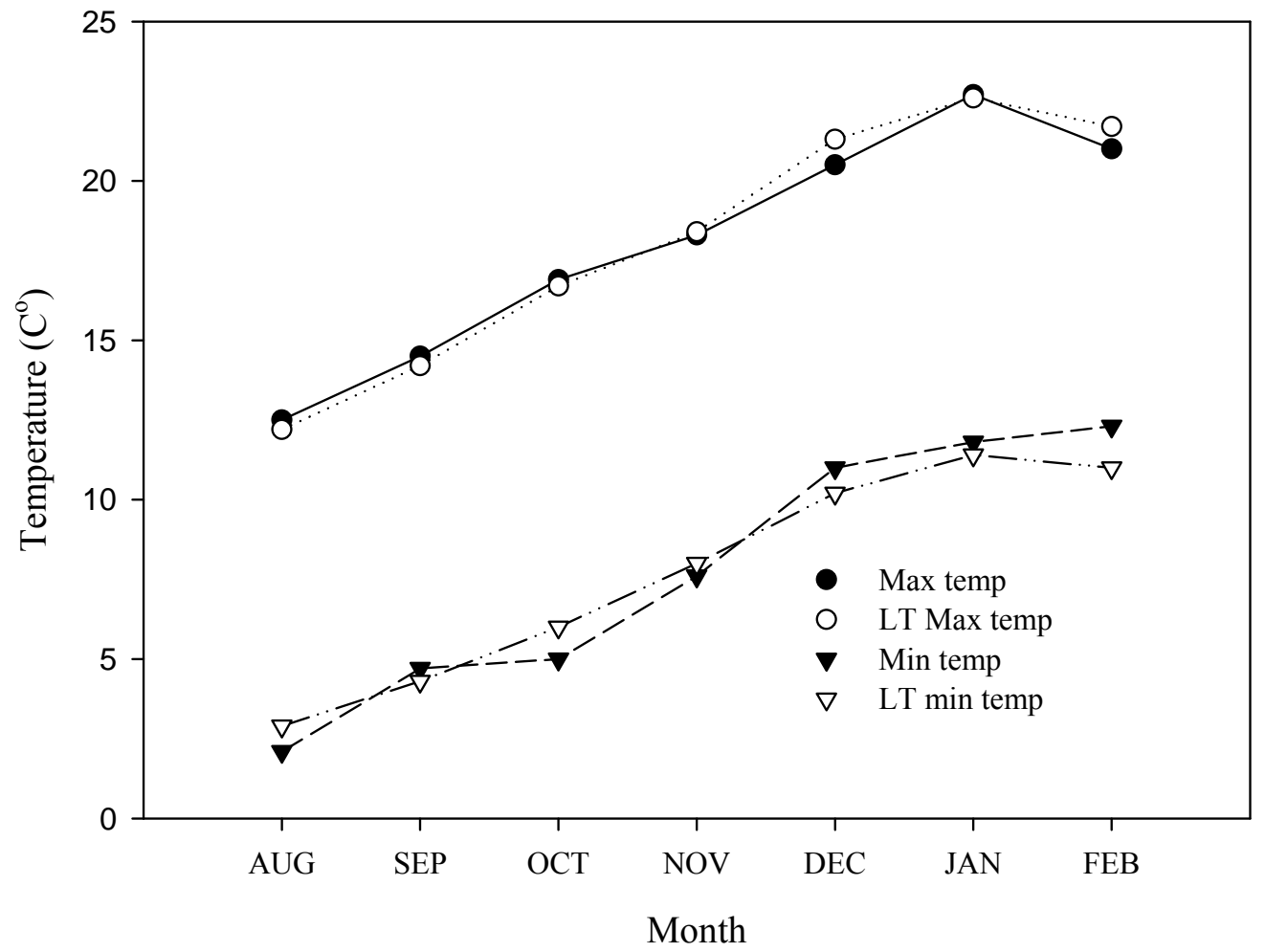

Fig. (2). Temperature data for Broadfields, Canterbury, in the 2007/08 growing season and the long-term mean 1975 - 1991.

Table 2. Total Dry Matter, Seed Yield, Crop Harvest Indices at Final Harvest of Field Peas Grown in Canterbury in the 2007/08 Growing Season (Experiment 1)

\begin{tabular}{|c|c|c|c|}
\hline & TDM $\left(\mathrm{g} \mathrm{m}^{-2}\right)$ & Seed yield $\left(\mathrm{gm}^{-2}\right)$ & CHI \\
\hline \hline \multicolumn{3}{|c|}{ Sowing date (S) } \\
\hline August & $1005 \mathrm{a}$ & $572 \mathrm{a}$ & $0.57 \mathrm{a}$ \\
\hline
\end{tabular}


Table 2. contd...

\begin{tabular}{|c|c|c|c|}
\hline & TDM $\left(\mathrm{g} \mathrm{m}^{-2}\right)$ & Seed yield $\left(\mathrm{gm}^{-2}\right)$ & CHI \\
\hline September & $1031 \mathrm{a}$ & $479 \mathrm{a}$ & $0.47 \mathrm{ab}$ \\
\hline October & $788 \mathrm{~b}$ & $354 b$ & $0.44 b$ \\
\hline Significance & $*$ & $* *$ & $* *$ \\
\hline LSD & 192.9 & 94.7 & 0.04 \\
\hline \multicolumn{4}{|c|}{ Herbicide (H) } \\
\hline $0 \mathrm{~g}$ a.i. ha $^{-1}$ & 852 & 428 & 0.50 \\
\hline $500 \mathrm{~g}$ a.i. $\mathrm{ha}^{-1}$ & 1030 & 508 & 0.49 \\
\hline Significance & $* * *$ & $* * *$ & NS \\
\hline LSD & 94.4 & 43.8 & - \\
\hline \multicolumn{4}{|c|}{ Pea type (T) } \\
\hline Midichi & 911 & 398 & 0.43 \\
\hline Pro 7035 & 971 & 539 & 0.56 \\
\hline Significance & NS & $* * *$ & $* * *$ \\
\hline LSD & - & 43.8 & 0.02 \\
\hline CV (\%) & 14.3 & 13.4 & 5.6 \\
\hline Significant interactions & Nil & SxT* & $\mathrm{SxT}^{* * *}$ \\
\hline
\end{tabular}

NS=Not significant at $0.05 ;{ }^{*} \mathrm{p}<0.05,{ }^{*} \mathrm{p}<0.01, * * * \mathrm{p}<0.001$

Table 3. The Sowing Date $x$ Pea Genotype Interaction on seed Yield of Field Peas Grown in Canterbury in the $2007 / 08$ Growing season (Experiment 1)

\begin{tabular}{|c|c|c|c|}
\hline & \multicolumn{3}{|c|}{ Sowing Date } \\
\hline Midichi & $547 \mathrm{ab}$ & $400 \mathrm{c}$ & $246 \mathrm{~d}$ \\
\hline Pro 7035 & $597 \mathrm{a}$ & $559 \mathrm{a}$ & $461 \mathrm{ac}$ \\
\hline Significance & & $*$ & \\
\hline CV (\%) & & 13.4 & \\
\hline
\end{tabular}

$* \mathrm{p}<0.05$

Table 4. The Sowing Date $x$ Pea Genotype Interaction on CHI of Field Peas Grown in Canterbury in the 2007/08 Growing Season (Experiment 1)

\begin{tabular}{|c|c|c|c|}
\hline & \multicolumn{2}{|c|}{ Sowing Date } \\
\hline \hline Pea genotype & August & September & October \\
\hline Midichi & $0.47 \mathrm{~b}$ & $0.32 \mathrm{~d}$ & $0.30 \mathrm{~d}$ \\
\hline Pro 7035 & $0.55 \mathrm{a}$ & $0.42 \mathrm{c}$ & $0.48 \mathrm{~b}$ \\
\cline { 1 - 3 } Significance & & $* *$ & \\
\cline { 1 - 3 } LSD & & 0.05 & \\
\cline { 3 - 4 } CV $(\%)$ & & 7.5 & \\
\hline
\end{tabular}

** $<<0.01$ 


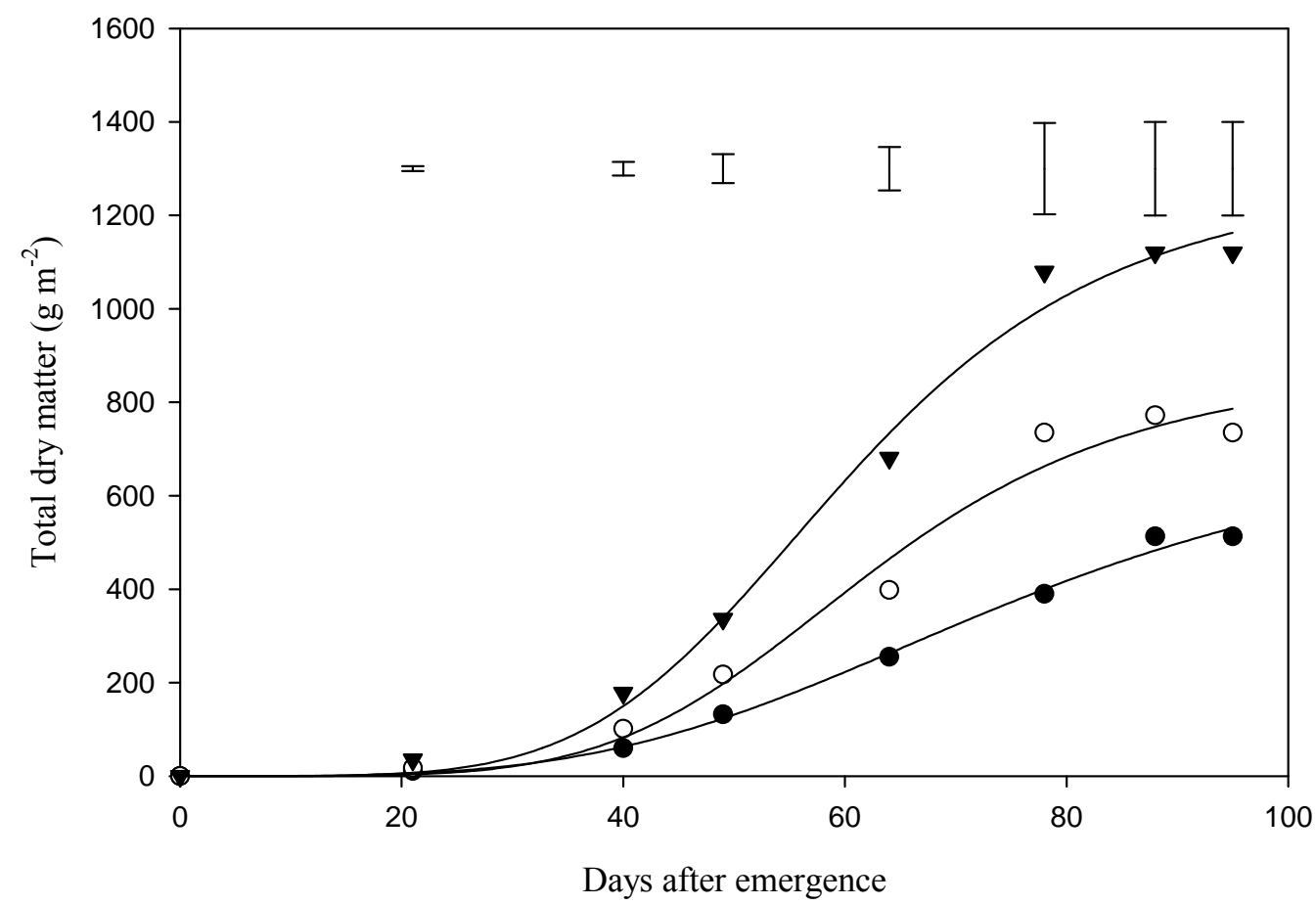

Fig. (3). Total dry matter accumulation of field peas, over time, grown in Canterbury in the 2007/08 growing season, pea population.

$(\bullet)=50$ plants $\mathrm{m}^{-2}$

(०) $=100$ plants $\mathrm{m}^{-2}$

$(\nabla)=200$ plants $\mathrm{m}^{-2}$

(Bars are LSD at $\mathrm{p}<0.05$ ).

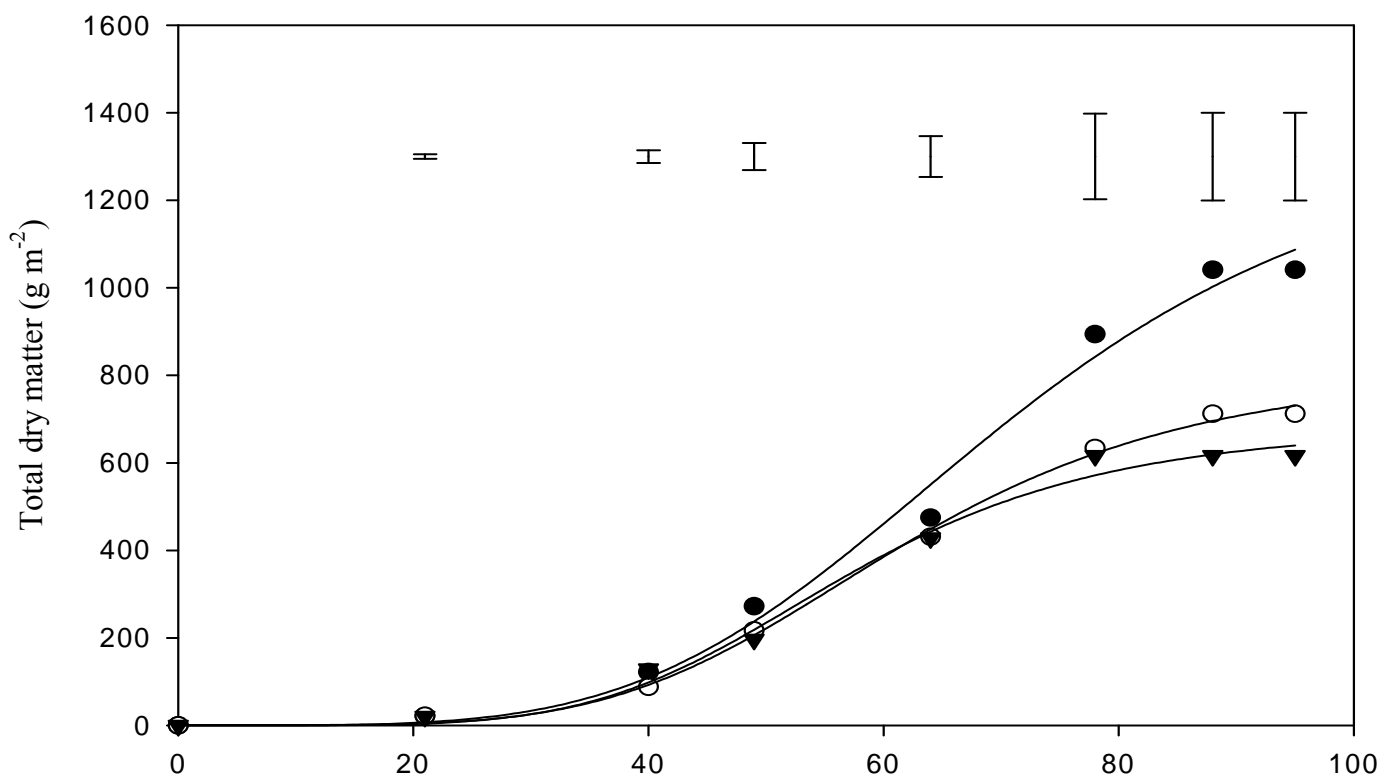

Days after emergence

Fig. (4). Total dry matter accumulation of field pea, over time, grown in Canterbury in the 2007/08 growing season, sown artificial weed population.

$(\bullet)=$ Nil

(०) = Low rate weed population

$(\nabla)=$ High rate weed population

(Bars are LSD at $\mathrm{p}<0.05$ ).

of the lowest pea population $\left(513 \mathrm{~g} \mathrm{~m}^{-2}\right)$ with sown weeds (Table 5). The control treatment (no-sown weeds) had the highest pea DM throughout the season. The low weed rate and the high weed rate treatments had similar DM accumulation throughout. However, the two were significantly different from the control treatment (Fig. 4). 
Table 5. Total Dry Matter, Seed Yield and Crop Harvest Index (CHI)) at Final Harvest of Field Peas Grown in Canterbury in the 2007/08 Growing Season (Experiment 2)

\begin{tabular}{|c|c|c|c|}
\hline & $\begin{array}{c}\text { Total Dry Matter } \\
\qquad\left(\mathrm{g} \mathrm{m}^{-2}\right)\end{array}$ & $\begin{array}{l}\text { Seed Yield } \\
\quad\left(\mathrm{g} \mathrm{m}^{-2}\right)\end{array}$ & CHI \\
\hline \multicolumn{4}{|c|}{ Pea Population (P) (Plants $\left.\mathrm{m}^{-2}\right)$} \\
\hline 50 & $513 \mathrm{c}$ & $197 \mathrm{c}$ & 0.39 \\
\hline 100 & $735 b$ & $294 b$ & 0.40 \\
\hline 200 & $1,120 \mathrm{a}$ & $409 \mathrm{a}$ & 0.37 \\
\hline Significance & $* * *$ & $* * *$ & NS \\
\hline LSD & 200.4 & 71 & - \\
\hline \multicolumn{4}{|c|}{ Sown Weed Population (W) } \\
\hline Nil & $1,041 \mathrm{a}$ & $390 \mathrm{a}$ & 0.37 \\
\hline Low weed rate & $712 b$ & $284 b$ & 0.31 \\
\hline High weed rate & $616 \mathrm{~b}$ & $226 \mathrm{~b}$ & 0.28 \\
\hline Significance & $* * *$ & $* * *$ & NS \\
\hline LSD & 200.4 & 71.0 & - \\
\hline CV $(\%)$ & 25.4 & 23.7 & 10.4 \\
\hline Significant interactions & Nil & Nil & Nil \\
\hline
\end{tabular}

NS=Not significant at $0.05 ;{ }^{*} \mathrm{p}<0.05,{ }^{* *} \mathrm{p}<0.01,{ }^{* * *} \mathrm{p}<0.001$

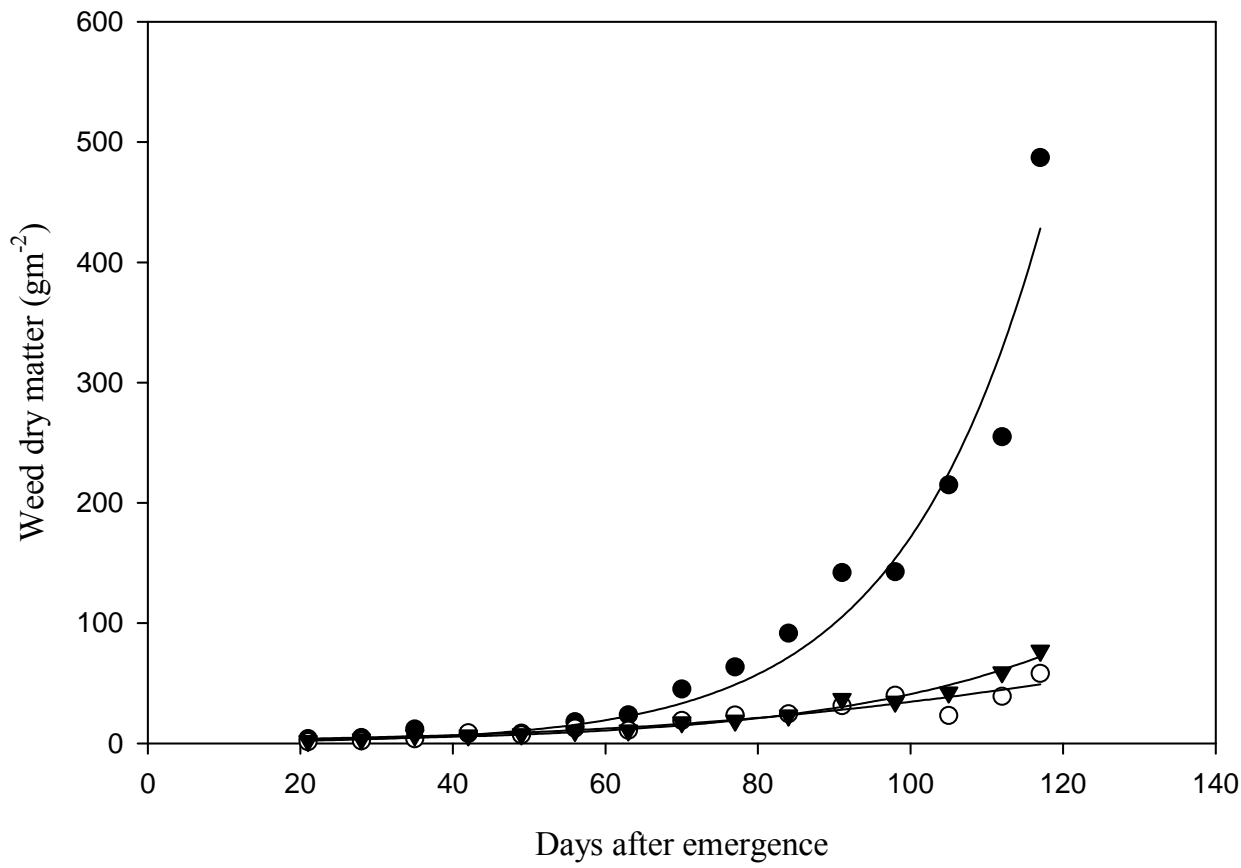

Fig. (5). Weed dry matter accumulation of field pea over time grown in Canterbury in the 2007/08 growing season, variety.

$(\bullet)=$ No pea

(०) = Midichi

$(\nabla)=$ Pro 7035

In experiment 2 seed yield increased significantly $(\mathrm{p}<$ 0.001 ) as pea population increased (Table 5). Two hundred pea plants $\mathrm{m}^{-2}$ gave the highest mean seed yield at $409 \mathrm{~g} \mathrm{~m}^{-2}$ and 50 pea plants $\mathrm{m}^{-2}$ the lowest at $197 \mathrm{~g} \mathrm{~m}^{-2}$. On the other hand the control treatment gave the highest mean seed yield of $390 \mathrm{~g} \mathrm{~m}^{-2}$. CHI did not vary and the grand mean was 0.39 .

\section{Total Weed Dry Matter}

In experiment 1 there was no difference in weed DM accumulation in response to pea genotype throughout until harvest when the no pea treatment plots had the highest weed DM (Fig. 5). Throughout the season there was more weed 


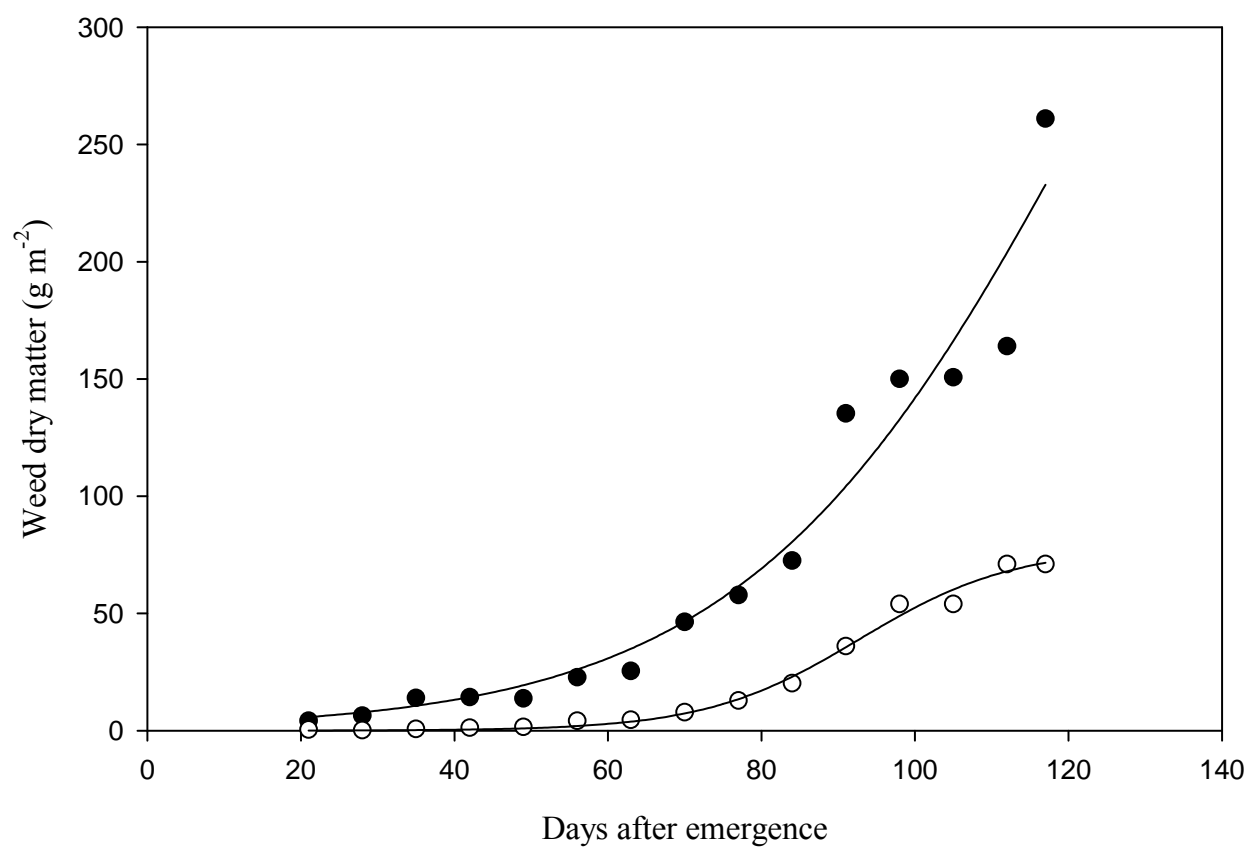

Fig. (6). Weed dry matter accumulation of field peas, over time, grown in Canterbury in the 2007/08 growing season, herbicide. $(\bullet)=$ Unsprayed

$(\circ)=$ Sprayed

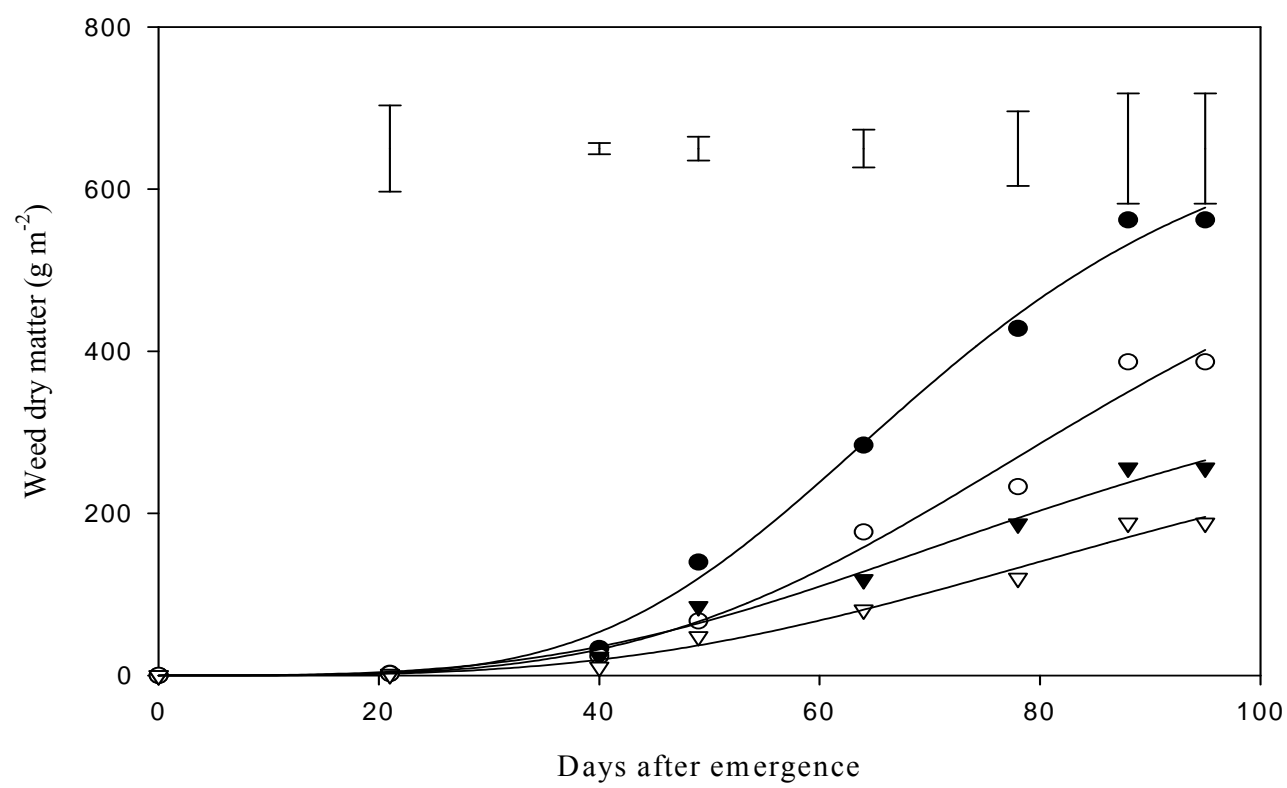

Fig. (7). Weeds total weed dry matter accumulation in field peas, over time, grown in Canterbury in the 2007/08 growing season, pea population.

$(\bullet)=0$ plants $\mathrm{m}^{-2}$

$(\circ)=50$ plants $\mathrm{m}^{-2}$

$(\nabla)=100$ plants $\mathrm{m}^{-2}$

$(\nabla)=200$ plants $\mathrm{m}^{-2}$,

(Bars are LSD at $\mathrm{p}<0.05$ ).

DM in unsprayed plots than in sprayed plots (Fig. 6). In experiment 2, weed DM always increased with decreased pea population throughout the season (Fig. 7). At final harvest, there was a $31 \%$ reduction in weed DM with an increase in pea population from 0 to 50 plants $\mathrm{m}^{-2}$ and a similar percentage decrease from 50 to 100 plants $\mathrm{m}^{-2}$ (Table 6). Overall, there was a $51 \%$ reduction in weed dry matter from 50 to 200 plants $\mathrm{m}^{-2}$. With sown weeds there was an increase in weed DM with increased weed population. The no-sownweed control plots had the lowest weed biomass throughout the season (Fig. 8). However, weed DM in the two sown weed treatments were not significantly different from each other but were significantly different from the no-sown weed treatment throughout the season.

\section{Weed Counts}

There was distinct variation in the weed spectrum over time in experiment 1 . Tables 7, 8 and $\mathbf{9}$ show weed counts for each sowing date. Generally, weed counts were lower in sprayed than in unsprayed plots and there were several sig 
Table 6. Weed Total Dry Matter $\left(\mathrm{g} \mathrm{m}^{-2}\right)$ at Final Harvest of Field Peas Grown in Canterbury in the 2007/08 Growing Season (Experiment 2)

\begin{tabular}{|c|c|}
\hline Pea Population (P) (Plants $\mathrm{m}^{-2}$ ) & Weed Total Dry Matter $\left(\mathrm{g} \mathrm{m}^{-2}\right)$ \\
\hline 0 & $562 \mathrm{a}$ \\
\hline 50 & $387 \mathrm{~b}$ \\
\hline 100 & $256 \mathrm{ac}$ \\
\hline 200 & $188 \mathrm{c}$ \\
\hline Significance & $* * *$ \\
\hline LSD & 136 \\
\hline \multicolumn{2}{|c|}{ Sown Weed Population (W) } \\
\hline Nil & $193 b$ \\
\hline Low weed rate & $399 \mathrm{a}$ \\
\hline High weed rate & $454 \mathrm{a}$ \\
\hline Significance & $* * *$ \\
\hline LSD & 118 \\
\hline CV $(\%)$ & 40 \\
\hline Significant interactions & Nil \\
\hline
\end{tabular}

$* * * \mathrm{p}<0.001$

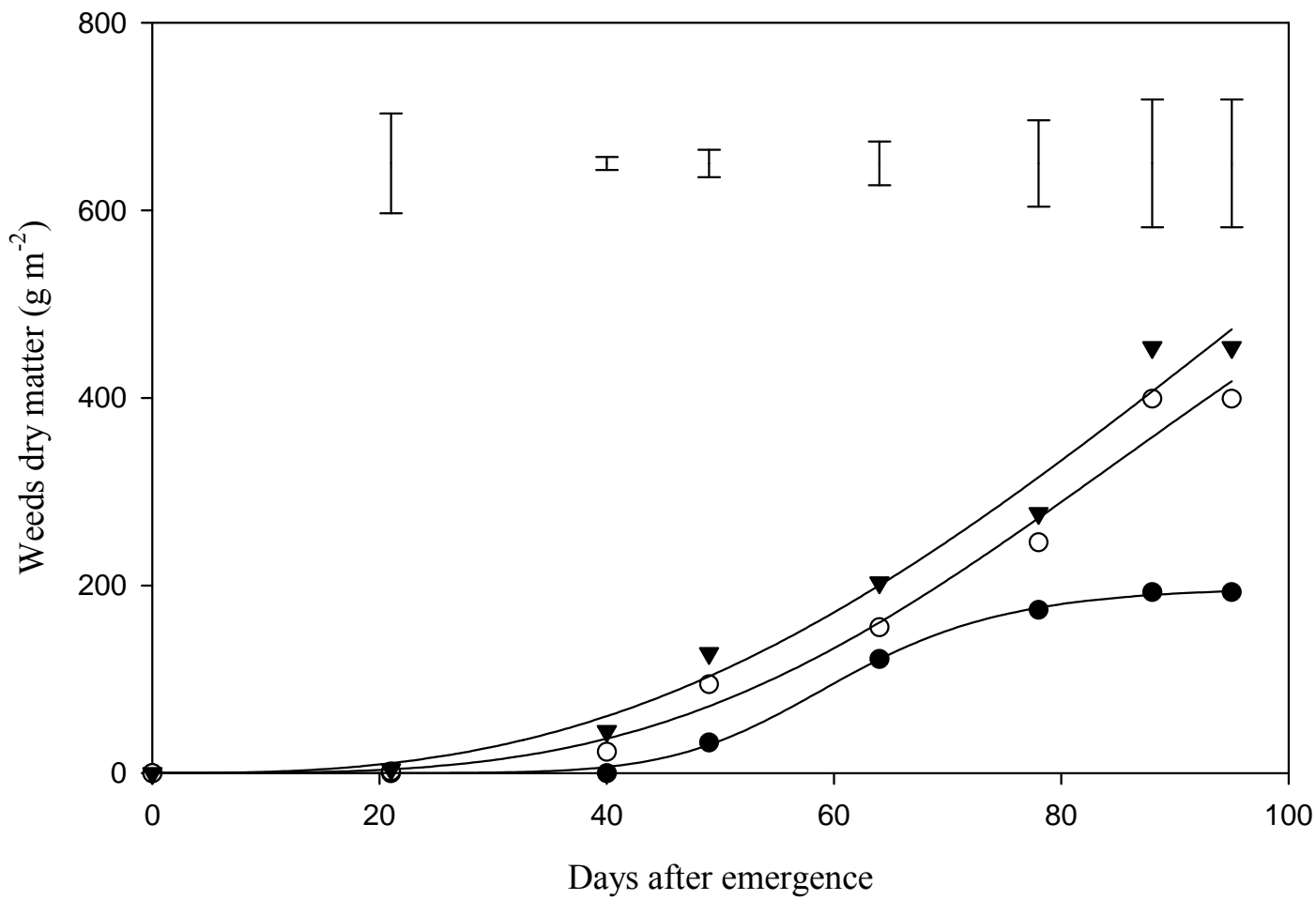

Fig. (8). Weed total dry matter accumulation in field peas, over time, grown in Canterbury in the 2007/08 growing season, sown artificial weed population.

$(\bullet)=$ Nil

$(\mathrm{O})$ Low rate weed population

$(\nabla)=$ High rate weed population

(Bars are LSD at $\mathrm{p}<0.05$ ). 
Table 7. The Density of Weeds $\left(\mathrm{m}^{-2}\right)$ Present after 10 Weeks in Field Peas Sown on 9 August 2007 (Experiment 1$)$

\begin{tabular}{|c|c|c|c|c|c|c|c|c|}
\hline & $\begin{array}{l}\text { Coronopus } \\
\text { spp. }\end{array}$ & $\begin{array}{l}\text { Lolium } \\
\text { spp }\end{array}$ & $\begin{array}{c}\text { Spergula Ar- } \\
\text { vensis }\end{array}$ & $\begin{array}{c}\text { Stellaria } \\
\text { Media }\end{array}$ & $\begin{array}{l}\text { Stachys } \\
\text { spp. }\end{array}$ & Others & Achillea Millefolium & $\begin{array}{l}\text { Total } \\
\text { Count }\end{array}$ \\
\hline \multicolumn{9}{|c|}{ Herbicide (H) } \\
\hline 0 g a.i. ha ${ }^{-1}$ & 233 & 43 & 29 & 112 & 18.9 & 42 & 3 & 524 \\
\hline $500 \mathrm{~g}$ a.i. $\mathrm{ha}^{-1}$ & 39 & 9 & 1 & 40 & 3.3 & 19 & 2 & 116 \\
\hline Significance & $* * *$ & $* * *$ & $* *$ & $*$ & NS & NS & NS & $* * *$ \\
\hline LSD & 19 & 14 & 18 & 63 & - & - & - & 95 \\
\hline \multicolumn{9}{|c|}{ Type (T) } \\
\hline No pea & 128 & 20 & 13 & 68 & 15 & 33 & 5 & 282 \\
\hline Midichi & 147 & 22 & 12 & 95 & 10 & 25 & 3 & 372 \\
\hline Pro 7035 & 133 & 37 & 20 & 65 & 8.3 & 33 & 0 & 307 \\
\hline Significance & NS & NS & NS & NS & NS & NS & NS & NS \\
\hline LSD & - & - & - & - & - & - & - & - \\
\hline Grand mean & 136 & 26 & 15 & 76 & 11 & 31 & 3 & 320 \\
\hline CV (\%) & 45 & 52 & 112 & 78 & 160 & 67 & 204 & 28 \\
\hline Significant interactions & Nil & Nil & Nil & Nil & Nil & Nil & Nil & Nil \\
\hline
\end{tabular}

NS=Not significant at $0.05 ;{ }^{*} \mathrm{p}<0.05,{ }^{* *} \mathrm{p}<0.01,{ }^{* * *} \mathrm{p}<0.001$

Table 8. The Density of Weeds $\left(\mathrm{m}^{-2}\right)$ Present after 10 Weeks in Field Peas Sown on 13 Sepetember 2007 (Experiment 1$)$

\begin{tabular}{|c|c|c|c|c|c|c|c|c|c|c|c|}
\hline & $\begin{array}{l}\text { Coronopus } \\
\text { spp. }\end{array}$ & $\begin{array}{l}\text { Lolium } \\
\text { spp }\end{array}$ & $\begin{array}{c}\text { Spergula } \\
\text { Arvensis }\end{array}$ & $\begin{array}{l}\text { Stellaria } \\
\text { media }\end{array}$ & $\begin{array}{c}\text { Chenopodium } \\
\text { spp }\end{array}$ & $\begin{array}{c}\text { Achillea } \\
\text { Millefolium }\end{array}$ & $\begin{array}{l}\text { Urtica } \\
\text { Urens }\end{array}$ & $\begin{array}{c}\text { Rumex } \\
\text { spp }\end{array}$ & $\begin{array}{c}\text { Capsella } \\
\text { Bursa- } \\
\text { Pastoris }\end{array}$ & Others & $\begin{array}{c}\text { Total } \\
\text { Count }\end{array}$ \\
\hline \multicolumn{12}{|c|}{ Herbicide (H) } \\
\hline 0 g a.i. ha ${ }^{-1}$ & 64 & 2 & 7 & 34 & 13 & 1 & 22 & 35 & 10 & 22 & 209 \\
\hline $500 \mathrm{~g}$ a.i. $\mathrm{ha}^{-1}$ & 12 & 3 & 1 & 2 & 4 & 2 & 6 & 3 & 2 & 21 & 55 \\
\hline Significance & $* * *$ & NS & $*$ & $* * *$ & $*$ & NS & $* * *$ & $* * *$ & $*$ & NS & $* * *$ \\
\hline LSD & 11 & - & 5 & 7 & 9 & - & 5 & 6 & 6 & - & 26 \\
\hline \multicolumn{12}{|c|}{ Type (T) } \\
\hline No Pea & 59 & 2 & 7 & 17 & 17 & 1 & 19 & 30.6 & 6 & 26 & 184 \\
\hline Midichi & 21 & 3 & 3 & 22 & 3 & 2 & 22 & 16 & 1 & 8 & 101 \\
\hline Pro 7035 & 34 & 1 & 2 & 16 & 6 & 2 & 1 & 9 & 11 & 29 & 111 \\
\hline Significance & $* * *$ & NS & NS & NS & $* * *$ & NS & $* * *$ & $* * *$ & $*$ & $* *$ & $* * *$ \\
\hline LSD & 14 & - & - & - & 11 & - & 6 & 7 & 8 & 13 & 32 \\
\hline Grand mean & 38 & 2 & 4 & 18 & 8 & 2 & 14 & 19 & 6 & 21 & 132 \\
\hline CV (\%) & 54 & 134 & 231 & 71 & 199 & 299 & 67 & 55 & 187 & 90 & 36 \\
\hline $\begin{array}{c}\text { Significant } \\
\text { interactions }\end{array}$ & $\mathrm{HxT}^{*}$ & $\mathrm{HxT}^{*}$ & Nil & $\mathrm{HxT}^{*}$ & Nil & Nil & $\mathrm{HxT}^{* * *}$ & $\mathrm{HxT}^{* * *}$ & Nil & $\mathrm{HxT}^{* *}$ & $\mathrm{HxT}^{* *}$ \\
\hline
\end{tabular}

NS=Not significant at $0.05 ;{ }^{*} \mathrm{p}<0.05,{ }^{*} \mathrm{p}<0.01,{ }^{* * *} \mathrm{p}<0.001$

Table 9. The Density of Weeds $\left(\mathrm{m}^{-2}\right)$ Present after 10 Weeks in Field Peas Sown on 15 October 2007 (Experiment 1$)$

\begin{tabular}{|c|c|c|c|c|c|c|c|c|c|c|c|}
\hline & $\begin{array}{c}\text { Coronopus } \\
\text { spp. }\end{array}$ & $\begin{array}{c}\text { Chenopodium } \\
\text { spp. }\end{array}$ & $\begin{array}{c}\text { Rumex } \\
\text { spp }\end{array}$ & $\begin{array}{c}\text { Lolium } \\
\text { spp }\end{array}$ & $\begin{array}{c}\text { Stellaria } \\
\text { Media }\end{array}$ & $\begin{array}{c}\text { Solanum } \\
\text { spp }\end{array}$ & $\begin{array}{c}\text { Trifolium } \\
\text { Repens }\end{array}$ & Others & Total Counts \\
\hline \hline 0
\end{tabular}


Table 9. contd...

\begin{tabular}{|c|c|c|c|c|c|c|c|c|c|}
\hline & $\begin{array}{l}\text { Coronopus } \\
\text { spp. }\end{array}$ & $\begin{array}{c}\text { Chenopodium } \\
\text { spp. }\end{array}$ & $\begin{array}{l}\text { Rumex } \\
\text { spp }\end{array}$ & $\begin{array}{l}\text { Lolium } \\
\text { spp }\end{array}$ & $\begin{array}{c}\text { Stellaria } \\
\text { Media }\end{array}$ & $\begin{array}{l}\text { Solanum } \\
\text { spp }\end{array}$ & $\begin{array}{c}\text { Trifolium } \\
\text { Repens }\end{array}$ & Others & Total Counts \\
\hline Significance & $* *$ & NS & $* * *$ & NS & NS & NS & NS & NS & $*$ \\
\hline \multicolumn{10}{|c|}{ Type (T) } \\
\hline No pea & 53 & 12 & 18 & 5 & 12 & 23 & 77 & 20 & 220 \\
\hline Pro 7035 & 32 & 8 & 8 & 15 & 20 & 13 & 52 & 22 & 170 \\
\hline Significance & NS & NS & NS & NS & NS & NS & NS & NS & NS \\
\hline LSD & - & - & - & - & - & - & - & - & - \\
\hline Grand mean & 42 & 12 & 14 & 14 & 14 & 17 & 46 & 20 & 179 \\
\hline
\end{tabular}

NS=Not significant at $0.05 ;{ }^{*} \mathrm{p}<0.05,{ }^{* *} \mathrm{p}<0.01, * * * \mathrm{p}<0.001$

nificant herbicide $\mathrm{x}$ pea genotype interactions on most major weeds. To summarise the interactions, significant differences of weed counts between the cyanazine sprayed plots and unsprayed plots was highest in the no pea control plots, followed by Midichi plots and the lowest was in Pro 7035.

\section{DISCUSSION}

A significant $(p<0.05)$ sowing date $x$ genotype interaction showed that in the August sowing genotype had no effect on seed yield. However in September sown plots the Pro 7035 seed yield of $559 \mathrm{~g} \mathrm{~m}^{-2}$ was $40 \%$ more than that Midichi. By October it was $87 \%$ more. This highlights the need to select a suitable genotype to use at different times in the season. Early in the season both genotypes could be used without yield reduction but as the season progressed, it was better to use a fully leafed genotype to smother the increased weed spectrum and numbers associated with the later sowing date, although both pea types were significantly better than the control no pea plots.

Genotype had no effect on seed yield in August because there were fewer weeds, which were slow growing with the low temperatures. This gave both pea genotypes (base temperature $4{ }^{\circ} \mathrm{C}$ ) the same competitive advantage over the weeds and hence the effect of weeds was not evident in that sowing. However, there was an increase in weed spectrum and quantity as the season progressed possibly attributable to increased temperatures so the effect of weeds and the differences in pea competitive ability against them of the different genotypes became evident.

Herbicide was effective in reducing weeds. Sprayed plots had a mean seed yield of $508 \mathrm{~g} \mathrm{~m}^{-2}$, which was $19 \%$ more than the mean of unsprayed plots. This shows the effect of weeds on crop yield through competition for nutrients, light, space, and water.

Seed yield increased significantly $(\mathrm{p}<0.001)$ as pea population increased. At 200 plants $\mathrm{m}^{-2}$ the highest mean seed yield of $409 \mathrm{~g} \mathrm{~m}^{-2}$ was obtained and at 50 plants $\mathrm{m}^{-2}$ it was the lowest $\left(197 \mathrm{~g} \mathrm{~m}^{-2}\right)$. Similarly, Townley-Smith and Wright [17] reported pea yield increases and weed DW reduction by raising field pea density from 50 to 100 seeds $\mathrm{m}^{-2}$, but concluded that increasing the seeding rate over 100 seeds $\mathrm{m}^{-2}$ would be unlikely to give a better result. According to them, a $70 \%$ increase in the seeding rate $\left(150\right.$ seeds $\mathrm{m}^{-2}$ compared with normal 90 seeds $\mathrm{m}^{-2}$ ) was costly in peas and could not always be compensated for by higher yield. Martin et al. [18] reported that increased plant density above 150 plants $\mathrm{m}^{-2}$ was not associated with a higher seed yield, although it did increase straw production. Similarly, White and Hill [12] recommended an optimum population of 70 plants $\mathrm{m}^{-2}$ on shallow soils, 90 plants $\mathrm{m}^{-2}$ on deeper soils and 100120 plants $\mathrm{m}^{-2}$ for irrigated pea crops in New Zealand. McKenzie et al. [19] reported optimum dry pea populations of $90-100$ plants $\mathrm{m}^{-2}$ but did not specify growing conditions.

Weed DM production was inversely proportional to pea population from 42 DAE until final harvest (Fig. 7). Increased pea population gave the crop a greater competitive advantage against weeds and a relatively higher TDM production and seed yield. The no-sown artificial weed treatment gave the highest mean seed yield of $390 \mathrm{~g} \mathrm{~m}^{-2}$ because it had just few weeds hence experienced the least competition. The reduction in pea TDM with increased weeds was basically because of competition for light and nutrients. Peas can clearly out compete weeds for light if sown at a higher than normally recommended population [8].

Marx and Hagedorn [20] reported that higher seeding rates of peas are effective in reducing weed development and Farshatov [21] found that raising the sowing rates of peas from $100-140$ plants $\mathrm{m}^{-2}$ reduced the weed population 2.5 fold. In this experiment there was a $31 \%$ reduction in weed DM with increased pea population from 0 to 50 plants $\mathrm{m}^{-2}$ and a similar percentage reduction from 50 to 100 plants $\mathrm{m}^{-2}$. Overall there was a $51 \%$ reduction from 50 to 200 pea plants $\mathrm{m}^{-2}$. Grevsen, [22] found a similar weed reduction and reported that increasing the seeding rate from the normal 90 
to 150 seeds $\mathrm{m}^{-2}$ reduced the dry weight of weed plants at harvest by $50 \%$ in 1997 and by $30 \%$ in 1998 . Results of this research support weed DM reductions as a result of crop population increases.

Environmental effects such as temperature might have caused the variation of weed spectrum at the different sowing dates. Coronopus didymus, Lolium spp and Stellaria media were found throughout the season. Cox, [23] classified Coronopus didymus as an early weed. Stellaria media grew well over a wide range of environments. Even early in the season, when temperatures were quite low, it was present in large numbers. This could be due to its low base temperature $\left(-3.3^{\circ} \mathrm{C}\right)$ [24]. Zimdahl [4] reported that common chickweed survives well in cold climates because it continues to grow in winter without injury. Another weed of similar interest recorded was Chenopodium album. Chenopodium album is one of the most widely distributed weed species in the world and ranks among the top three important weeds of cereals in New Zealand [6, 12]. Contrary to the findings of Myers et al. [25] that it is an early weed in United States of America, in this research it occurred during mid to late season. Cox, [22] classified it as a late weed in New Zealand. Achillea millefolium emerged early and during mid season, and could have had a major role in reducing the yield of early sown peas. It is considered as a common, successful, hard-line weed on arable land in New Zealand [26]. Hartley et al. [27] reported that the success of this weed is also attributed to its persistent, vigorous rhizomes. Bourdôt and Butler [28] reported that it grew throughout the year and spread laterally, by rhizome extension, particularly in the winter months in Canterbury.

Under this research late weeds were Trifolium repens and Solanum spp. Nightshades have a base temperate of $6{ }^{\circ} \mathrm{C}$ [29] and this explains why they usually grow late in the season when temperatures are warmer. Myers et al. [24] also reported nightshades were late weeds. Isaac [6], reported higher Trifolium repens counts in late sown crops than in early sown crops confirming that it is a late weed.

\section{CONCLUSIONS}

\section{The Following Conclusions were Drawn Out of the Re-} search

There was a significant sowing date $\mathrm{x}$ genotype on seed yield that indicated the need to use specific genotypes for different sowing times.

- Pea yield could be increased by increasing pea population especially in weedy environments.

- Weed spectrum changed over the season.

- Early sowing could possibly control problem weeds of peas (particularly Solanum spp) by avoiding competition from this weed.

- Pea genotype alone did not have any direct effect on weed suppression.

\section{CONFLICT OF INTEREST}

The authors confirm that this article content has no conflicts of interest.

\section{ACKNOWLEDGEMENTS}

This work would not have been possible without input from some special people and organisations, which I feel greatly indebted to acknowledge. Lincoln University Research Committee funded this research. Plant Research New Zealand limited provided the pea seed and the fungicides that were used for all the trials. My thanks go to my research associates, Profs. B. A. McKenzie and G. D. Hill for their contribution in writing this paper and to Messrs Don Heffer, Dave Jack, Malcom Smith, Dr Keith Pollock for the technical assistance. Dr. R. Sedcole contributed on the statistical analysis. I also want to acknowledge the reviewers of this paper for the very valuable contributions.

\section{REFERENCES}

[1] Melander B. Modelling the effects of Elysmus repens L. (Gould). Competition on yield of cereals, peas and oilseed rape. Weed Res 1993; 33: 99-108.

[2] Lutman PJW, Dixon FL, Risiott R. The response of four Spring sown combinable arable crops to weed competition. Weed Res 1994; 34: 137-46.

[3] Freeman CL. In: Jermyn WA, Wratt GS. Eds. Growing peas under irrigation. Peas: management for quality. Agronomy Society of New Zealand, Special Publication No. 6, 1987; pp. 19-21.

[4] Zimdahl RL. Fundamentals of Weed Science. $3^{\text {rd }}$ ed. London: Academic Press 2007.

[5] Radosevich S, Holt J, Ghersa C. Weed Ecology - Implications for Management, $2^{\text {nd }}$ ed. Johns Wiley \& Sons: New York 1997; p. 589.

[6] Isaac WAP. Contribution of crop morphological characteristics and density of selected crops to weed species composition and suppression. Unpublished MAgrSc thesis, Lincoln University, Canterbury, New Zealand 2001.

[7] Blackshaw RE, Anderson RL, Lemerle D. In: Upadhyaya MK, Blackshaw RE, Eds. Cultural weed management. Non-Chemical Weed Management, Principles, Concepts and Technology. Agriculture and Agri-Food Canada: Lethbridge 2007; pp. 35-47.

[8] McDonald GK, Hollaway KL, McMurray L. Increasing plant density improves weed competition in lentils (Lens culinaris). Aust $\mathrm{J}$ Exp Agric 2007; 47: 48-56.

[9] Burnside OC. Tolerance of soybean cultivars to weed competition and herbicides. Weed Sci 1972; 20 (4): pp. 294-7.

[10] Harker KN, Blackshaw RE, Clayton GW. Wild oat (Avena fatua) vs Redstem Filaree (Erodium cicutarium) interference in dry pea. Weed Technol 2007; 21 (1): 235-40.

[11] Moot DJ. Harvest Index variability within and between field pea (Pisum sativum L.) crops. Unpublished PhD thesis, Lincoln University, Canterbury, New Zealand 1993.

[12] White JW, Hill GD. In: White J, Hodgson J, Eds. Grain Legumes. Australia: N Z Pasture Crop Sci Oxford 1999; pp. 235-47.

[13] McKenzie BA. The growth development and water use of lentils (Lens culinaris Medik). Unpublished PhD thesis, Lincoln College, University of Canterbury: New Zealand 1987.

[14] Moot DJ, McNeil DL. Yield components, harvest index and plant type in relation to yield differences in field pea genotypes. Euphytica 1995; 86: 31-40.

[15] Department of Scientific and Industrial Research, N Z, Soil Bureau. General survey of the soils of the South Island. New Zealand. Soil Bureau Bulletin 1968; 27.

[16] Taylor NH, Pohlem IJ. Soil survey method. N Z, Soil Bureau Bulletin $1962 ; 25$.

[17] Townley-Smith L, Wright AT. Field pea cultivar and weed response to crop seed rate in Western Canada. Can J Plant Sci 1994; 74: 387-93.

[18] Martin I, Tenorio JL, Ayerbe L. Yield and evapotranspiration of leafed and semi-leafless peas with different plant populations under drought conditions. Proceedings $1^{\text {st }}$ European Conference on Grain Legumes, Anger France 1992; pp. 211-12.

[19] McKenzie BA, Hampton JG, White H, et al. In: White J, Hodgson J Eds. Annual crop production principles. NZ Pasture Crop Sci Oxford: Australia 1999; pp. 199-12.

[20] Marx GA, Hagedorn DJ. Plant population and weed growth relations in canning peas. Weeds 1961; 9: 494-6. 
[21] Farshatov MSH. The effect of sowing methods and rates on weed population in peas. Shornik Trudor Bashkirshago Sel Skokhozyaistvernogo Instituta 1973; 17: 162-4.

[22] Grevsen K. Weed competitive ability of green peas (Pisum sativum L.) affected by seeding rate and genotype characteristics. Biol Agric Hortic 2003; 21: 247-61.

[23] Cox TI. Weeds in spring seedbeds. Proc NZ Weed Pest Control Conf 1977; 30: 1-7.

[24] Storkey J, Cussans JW. Relationship between temperature and the early growth of Triticum aestivum and three weed species. Weed Sci 2000; 48 (4): 467-73.

[25] Myers MW, Curran WS, VanGessel MJ, et al. Predicting weed emergence for eight annual species in the north eastern United States. Weed Sci 2004; 52: 913-9.
[26] Bourdôt GW, Field RJ. A review of the ecology and control of Achillea millefolium L. (yarrow) on arable in New Zealand. N Z J Exp Agric 1988; 16: 99-108.

[27] Hartely MJ, Lyttle LA, Popay AI. Control of Carlifonia thistle by grazing management. Proceedings of the 37th New Zealand Weed and Pest Control Society Conference 1984; pp. 24-27.

[28] Bourdôt GW, Butler JHB. Control of Achillea millefolium L. (yarrow) by rotary cultivation and glyphosate. Weed Res 1985; 25 : 251-8.

[29] Olivier FC, Annandale JG. Thermal requirements for the development of green pea (Pisum sativum.L.). Field Crops Res 1998; 56: 301-7.

(C) Munakamwe et al.; Licensee Bentham Open.

This is an open access article licensed under the terms of the Creative Commons Attribution Non-Commercial License (http:/creativecommons.org/licenses/by-nc/3.0/) which permits unrestricted, non-commercial use, distribution and reproduction in any medium, provided the work is properly cited. 